NASA/TM-2002-211550

\title{
Particle Size Effects on Flow Properties of PS304 Plasma Spray Feedstock Powder Blend
}

Malcolm K. Stanford

University of Dayton, Dayton, Ohio

Christopher DellaCorte

Glenn Research Center, Cleveland, Ohio

Daniel Eylon

University of Dayton, Dayton, Ohio 
Since its founding, NASA has been dedicated to the advancement of aeronautics and space science. The NASA Scientific and Technical Information (STI) Program Office plays a key part in helping NASA maintain this important role.

The NASA STI Program Office is operated by Langley Research Center, the Lead Center for NASA's scientific and technical information. The NASA STI Program Office provides access to the NASA STI Database, the largest collection of aeronautical and space science STI in the world. The Program Office is also NASA's institutional mechanism for disseminating the results of its research and development activities. These results are published by NASA in the NASA STI Report Series, which includes the following report types:

- TECHNICAL PUBLICATION. Reports of completed research or a major significant phase of research that present the results of NASA programs and include extensive data or theoretical analysis. Includes compilations of significant scientific and technical data and information deemed to be of continuing reference value. NASA's counterpart of peerreviewed formal professional papers but has less stringent limitations on manuscript length and extent of graphic presentations.

- TECHNICAL MEMORANDUM. Scientific and technical findings that are preliminary or of specialized interest, e.g., quick release reports, working papers, and bibliographies that contain minimal annotation. Does not contain extensive analysis.

- CONTRACTOR REPORT. Scientific and technical findings by NASA-sponsored contractors and grantees.
- CONFERENCE PUBLICATION. Collected papers from scientific and technical conferences, symposia, seminars, or other meetings sponsored or cosponsored by NASA.

- SPECIAL PUBLICATION. Scientific, technical, or historical information from NASA programs, projects, and missions, often concerned with subjects having substantial public interest.

- TECHNICAL TRANSLATION. Englishlanguage translations of foreign scientific and technical material pertinent to NASA's mission.

Specialized services that complement the STI Program Office's diverse offerings include creating custom thesauri, building customized data bases, organizing and publishing research results ... even providing videos.

For more information about the NASA STI Program Office, see the following:

- Access the NASA STI Program Home Page at $h t t p: / / w w w . s t i . n a s a . g o v$

- E-mail your question via the Internet to help@sti.nasa.gov

- Fax your question to the NASA Access Help Desk at 301-621-0134

- Telephone the NASA Access Help Desk at 301-621-0390

- Write to: NASA Access Help Desk NASA Center for AeroSpace Information 7121 Standard Drive Hanover, MD 21076 
NASA/TM-2002-211550

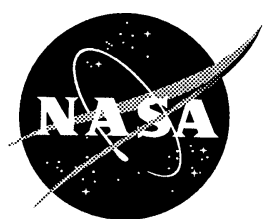

Particle Size Effects on Flow Properties of PS304 Plasma Spray Feedstock Powder Blend

Malcolm K. Stanford

University of Dayton, Dayton, Ohio

Christopher DellaCorte

Glenn Research Center, Cleveland, Ohio

Daniel Eylon

University of Dayton, Dayton, Ohio

National Aeronautics and

Space Administration

Glenn Research Center 


\section{Acknowledgments}

The authors would like to express their sincere gratitude to Dr. N.L. Hecht, who reviewed this work and provided helpful comments. The use of facilities at the University of Dayton Research Institute Center for Materials Diagnostics (UDRI CMD) provided by Dr. N. Meyendorf is truly appreciated. Thank you to Ms. C. Seitz and Ms. C. O'Brien for gracious administrative assistance and to Messrs. T. Campbell, D. Dixon, V. Lukaszewicz, and A. Zaldana for tireless technical assistance. This work was conducted by the primary author while receiving support from NASA and the Dayton Area Graduate Studies Institute (DAGSI), which are gratefully appreciated.

This report contains preliminary

findings, subject to revision as

analysis proceeds.

The Aerospace Propulsion and Power Program at

NASA Glenn Research Center sponsored this work.

Available from

NASA Center for Aerospace Information

7121 Standard Drive

National Technical Information Service 5285 Port Royal Road

Hanover, MD 21076

Springfield, VA 22100

Available electronically at http://gltrs.grc.nasa.gov/GLTRS 


\title{
Particle Size Effects on Flow Properties of PS304 Plasma Spray Feedstock Powder Blend
}

\author{
Malcolm K. Stanford \\ Materials Engineering \\ University of Dayton \\ Dayton, Ohio 45469-0121 \\ Christopher DellaCorte \\ National Aeronautics and Space Administration \\ Glenn Research Center \\ Cleveland, Ohio 44135-3191 \\ Daniel Eylon \\ Materials Engineering \\ University of Dayton \\ Dayton, Ohio 45469-0240
}

\begin{abstract}
The effects of $\mathrm{BaF}_{2}-\mathrm{CaF}_{2}$ particle size and size distribution on $\mathrm{PS} 304$ feedstock powder flowability have been investigated. Angular $\mathrm{BaF}_{2}-\mathrm{CaF}_{2}$ eutectic powders were produced by comminution and classified by screening to obtain 38 to $45 \mu \mathrm{m}, 45$ to $106 \mu \mathrm{m}, 63$ to $106 \mu \mathrm{m}, 45$ to $53 \mu \mathrm{m}, 63$ to $75 \mu \mathrm{m}$, and 90 to $106 \mu \mathrm{m}$ particle size distributions. The fluorides were added incrementally from 0 to $10 \mathrm{wt} \%$ to the other powder constituents of the PS304 feedstock: nichrome, chromia, and silver powders. The flow rate of the powder blends decreased linearly with increasing concentration of the fluorides. Flow was degraded with decreasing $\mathrm{BaF}_{2}-\mathrm{CaF}_{2}$ particle size and with increasing $\mathrm{BaF}_{2}-\mathrm{CaF}_{2}$ particle size distribution. A semi-empirical relationship is offered to describe the PS304 powder blend flow behavior. The Hausner Ratio confirmed the funnel flow test results, but was slightly less sensitive to differences in $\mathrm{BaF}_{2}-\mathrm{CaF}_{2}$ particle size and size distribution. These findings may have applicability to other powders that do not flow easily, such as ceramic powders.
\end{abstract}

\section{Introduction}

PS304 is a plasma spray deposited coating for the reduction of friction and wear in turbomachinery applications [1-6]. The feedstock for this coating is a powder blend consisting of nichrome, chromia, silver and eutectic barium fluoride-calcium fluoride. Experience has indicated that the flow characteristics of the powder blend are highly dependent upon the size of the $\mathrm{BaF}_{2}-\mathrm{CaF}_{2}$ constituent. This paper reports the relationship between $\mathrm{BaF}_{2}-\mathrm{CaF}_{2}$ size and the flowability of the PS304 feedstock powder. The objective of this investigation was to establish the role of $\mathrm{BaF}_{2}-\mathrm{CaF}_{2}$ particle size and size distribution in PS304 feedstock flowability in order to improve feedstock characteristics and enhance the commercial potential of the PS304 coating.

The ability to understand and predict powder flow behavior is important to the handling and processing of granular materials in a broad range of industries including thermal spray technology, ceramics, powder metallurgy, pharmaceuticals, concrete, powdered foods and many others [7-10]. Therefore, this work is expected to help add insight to similar powder flow problems encountered in the manufacturing operations of a variety of disciplines. 


\section{Background}

The PS304 coating was developed at NASA Glenn Research Center [11] for the reduction of sliding friction and wear in turbomachinery applications at temperatures from sub-ambient up to $650{ }^{\circ} \mathrm{C}$. The composition of this coating is $60 \mathrm{wt} \%$ nichrome $(80 \mathrm{Ni}-20 \mathrm{Cr}), 20 \mathrm{wt} \%$ chromia $\left(\mathrm{Cr}_{2} \mathrm{O}_{3}\right), 10 \mathrm{wt} \%$ silver and $10 \mathrm{wt} \%$ eutectic barium fluoride-calcium fluoride $\left(70 \mathrm{BaF}_{2}-30 \mathrm{CaF}_{2}\right)$. Nichrome serves as a binder and, along with chromia, provides wear resistance. Silver and $\mathrm{BaF}_{2}-\mathrm{CaF}_{2}$ are solid lubricants at low and high temperatures, respectively. The coating is deposited on the sliding surfaces of the components by plasma spray.

In the plasma spray process particles of the deposition material are injected into a plasma flame, which is produced by the ionization of an inert gas [12]. The plasma heats the particles to a molten or semi-molten state. The particles then strike the substrate and quickly solidify. The impact of subsequent particles increases the thickness of the coating layer. The feedstock is prepared in a powdered form to facilitate control of the rapid melting and re-solidification of the coating material. Where multicomponent coating systems are to be deposited, the feedstock can be a powder blend composed of the different coating constituents.

In a preliminary study, it was determined that intermittent clogging of powder flow in the plasma spray powder feeding system was caused by the $\mathrm{BaF}_{2}-\mathrm{CaF}_{2}$ particles [13]. When the $\mathrm{BaF}_{2}-\mathrm{CaF}_{2}$ particles were smaller than $40 \mu \mathrm{m}$, the feedstock powder had poor flow characteristics.

The $\mathrm{BaF}_{2}-\mathrm{CaF}_{2}$ powder used in this study was produced by comminution. This process takes advantage of the naturally occurring flaws in ceramic materials such as microcracks, voids and grain boundaries, shown schematically in figure 1 [14], as well as their inherent brittleness. When stress is applied to the bulk material, fracture begins along these defects leading to size reduction. Although comminution is a well-established process, the control of yield particle size and size distribution remains a difficult problem [15]. This is due in part to the fact that size reduction is highly dependent upon the processing history of the bulk material, which determines the flaw size and population in the material [16]. The higher the defect density, the more easily the bulk material can be comminuted. However, the density and distribution of the flaws are difficult to assess. In addition, the well-known relationships between energy imparted to a material during comminution and resultant particle sizes are typically impractical due to the inefficiency of actual energy transfer to the material [17-18]. The typical yield particle sizes tend to be predominantly fine. The bulk $\mathrm{BaF}_{2}-\mathrm{CaF}_{2}$ material used in this study tends to fracture such that about $70 \mathrm{wt} \%$ of the particles are smaller than $40 \mu \mathrm{m}$. Due to poor flowability, material of this size can be utilized only after additional fusion and comminution, which adds cost to the process. This brings about a need for a detailed study of the ways in which particle size affects flow characteristics of PS304 feedstock.

\section{Approach}

As the size of a particle decreases, the ratio of its surface area to mass increases. Since interparticle surface forces such as friction and cohesion are determined by the total surface area, and since mass is proportional to the volume, the surface area to volume ratio is a good general indication of the flowability of a powder system [19-20]. The higher the surface area to volume ratio, the more propensity a powder particle has to cling to another particle rather than to fall away under the influence of gravity, reducing the ability of the powder to flow. For some powders, an addition of as little as $5 \mathrm{wt} \%$ of particles smaller than $40 \mu \mathrm{m}$ has been found to halt the flow of the powder system [14]. Additionally, wider particle size distributions allow better particle packing, increasing the average coordination number, thereby increasing interparticle friction [21]. In general, flow of a powder system may be affected by particle size and size distribution, particle shape and shape distribution, surface chemistry, density and the surrounding 
medium [22-23]. The effects of $\mathrm{BaF}_{2}-\mathrm{CaF}_{2}$ particle shape and the humidity of the surrounding medium on the flowability of this powder blend are described elsewhere [24-25].

Techniques for analyzing the interparticle forces that determine the flow behavior of powder systems under the influence of gravity include use of the Hall flowmeter and the measurement of the Hausner Ratio. The Hall flowmeter is a standard device for investigation of the flow characteristics of powder systems [26]. The Hall flowmeter has been used in a recent study to characterize the flow rate of other composite plasma spray feedstock powders [10]. This instrument was a reliable indicator of the flowability of feedstock powder for the studied plasma spray system. Powders that consistently flowed through the plasma spray powder feed hopper also flowed through the Hall funnel. Conversely, powders that did not flow through the plasma spray system did not flow through the flowmeter. The flow test measures the time required for $50 \mathrm{~g}$ of powder to exit a calibrated funnel. This measurement is designated the flow time. As the interparticle friction increases in a powder system, the flow time increases. A free flowing powder flows through the Hall funnel unaided under the influence of gravity.

The Hausner Ratio is the ratio of the tapped density to the apparent (or poured) density of the powder [23]. The apparent density tends to decrease as the interparticle friction in a powder system increases [27]. The tapped density tends to decrease as well, though at a lesser rate due to the additional energy imparted to the system from the tapping. Therefore, a cohesive powder will have a higher Hausner Ratio than one that is free flowing. Hausner Ratio values greater than 1.5 are generally believed to identify a powder that is not free flowing $[23,28]$. This study will investigate the correlation between the Hausner Ratio and the Hall flowmeter results for PS304 feedstock powder.

\section{Experimental Procedure}

Figure 2 shows the constituents of PS304. The nichrome particles shown in figure $2 \mathrm{a}$ are 44 to $74 \mu \mathrm{m}$ in size and have a rounded shape. The chromia particles shown in figure $2 \mathrm{~b}$ are 30 to $44 \mu \mathrm{m}$ in size and have an angular morphology. The spherical silver particles shown in figure $2 \mathrm{c}$ are 45 to $100 \mu \mathrm{m}$ in diameter. These three powders are available commercially and their sizes and shapes were not modified for this study.

The $\mathrm{BaF}_{2}-\mathrm{CaF}_{2}$ particles shown in figure $2 \mathrm{~d}$ were 45 to $106 \mu \mathrm{m}$ in size and have an angular shape. This powder was fabricated by comminution. For this procedure, blocks of the fused eutectic material that were on the order of $5 \mathrm{~cm}$ in size were fed into a jaw crusher. A jaw crusher reduces the size of a brittle material by compressing it between two plates [29]. One plate provides a reciprocating crushing motion, while the other remains stationary. The plates are inclined with respect to one another such that the gap between them narrows toward the bottom. The dimension of the gap at the narrowest point determines the final size of the reduced material. The resultant powder, collected in a bin below the crushing jaws, has the texture of fine gravel.

A disk mill is used to perform the next $\mathrm{BaF}_{2}-\mathrm{CaF}_{2}$ particle size reduction step. A disk mill works by subjecting the material collected from the primary size reduction operation to shear and compressive forces between two opposing disks, one rotating and the other stationary. The disks have teeth that are oriented radially and inclined such that the gap between them decreases toward their circumferences. The material is fed into the area between the centers of the two disks. The rotating disk forces the material radially outward due to centrifugal forces. The final particle size is determined by the smallest gap between the disks.

ASTM standard specification B 214-99 was used to classify the fluorides by size. The screens used in this procedure were manufactured according to ASTM standard specification E-11. The screens were stacked vertically in order of coarsest mesh to finest mesh. The screen mesh sizes used were numbers $140,170,200,230,270$, and 325 . The screening instrument uses a vertically oscillating column of air and a combination of vertical and horizontal tappers to separate the particles according to size. The fluorides were classified by screening to obtain 38 to $45 \mu \mathrm{m}, 45$ to $106 \mu \mathrm{m}, 63$ to $106 \mu \mathrm{m}, 45$ to $53 \mu \mathrm{m}, 63$ to $75 \mu \mathrm{m}$, and 90 to $106 \mu \mathrm{m}$ particle size distributions. 
The flow rate of each powder blend was tested according to ASTM B 213-97. For this test, a $50 \mathrm{~g}$ sample of the powder blend being tested was loaded into a Hall flowmeter. A schematic of the test apparatus is shown in figure 3 . For each flow test, a powder blend consisting of $60 \mathrm{~g}$ nichrome, $20 \mathrm{~g}$ chromia, $10 \mathrm{~g}$ silver and an incrementally increasing amount of fluorides ( 0 to $10 \mathrm{wt} \%)$ was prepared by mixing the constituents together in a $125 \mathrm{~mL}$ high density polyethylene bottle until well blended. A $50.0 \mathrm{~g}$ sample was obtained from the powder blend for flow testing. A digital stopwatch was used to measure the time it took the entire sample to exit the funnel. The test was repeated, the times were averaged to the nearest $0.1 \mathrm{~s}$ and designated the flow time. The data were reported on a plot of flow time versus the weight fraction of fluorides in the powder blend.

The tapped density was measured according to ASTM B 527-93. A 50g sample of the powder blend containing $10 \mathrm{wt} \% \mathrm{BaF}_{2}-\mathrm{CaF}_{2}$ was poured into a $25 \mathrm{~cm}^{3}$ graduated cylinder with $0.5 \mathrm{~cm}^{3}$ divisions. The tapping apparatus dropped the cylinder through a stroke of $3 \mathrm{~mm}$ at a frequency of approximately 250 taps per minute. The volume the powder occupied after 3,000 taps $v_{t}$ was then recorded to the nearest $0.5 \mathrm{~cm}^{3}$. The tapped density was then calculated as the mass of the powder divided by the volume it occupied, $50 \mathrm{~g} / v_{t}$.

The apparent density was measured according to ASTM B 212-99. The powder blend containing $10 \mathrm{wt} \% \mathrm{BaF}_{2}-\mathrm{CaF}_{2}$ was poured into a $25 \mathrm{~cm}^{3}$ brass cup using the Hall funnel. When the powder filled the cup to overflowing, the funnel was swiveled about $90^{\circ}$ to stop the powder flow into the cup. A metallic spatula was used to level the powder to the top edge of the cup. The cup with the powder was then transferred to the scale. The mass of the powder $m_{a}$ was recorded to the nearest $0.1 \mathrm{~g}$. The apparent density was then calculated as the mass of the powder divided by the volumetric capacity of the cylinder, $m_{a} / 25 \mathrm{~cm}^{3}$. The reported value for tapped density and apparent density was the average of three measurements. All flow tests and density measurements were performed at room temperature.

\section{Results and Discussion}

The $\mathrm{BaF}_{2}-\mathrm{CaF}_{2}$ particles collected from the jaw crusher were smaller than $2 \mathrm{~mm}$. The particles subsequently collected from the disk mill were smaller than $200 \mu \mathrm{m}$. The weight percentages of the comminuted fluorides per screening run are shown in figure 4 . The powder that was not retained on the screens ( $\sim 67$ percent) passed through the 325 mesh screen and was collected in the pan. Equal mass distributions were prepared for the $\mathrm{BaF}_{2}-\mathrm{CaF}_{2}$ particle size ranges shown in table 1 . The reported flow time is the average of two consecutive tests. The results of the flow tests are shown graphically in figure 5 .

The flow time increased linearly with increasing concentration of fluorides, indicating an increase in the overall interparticle friction in the powder blend due to the addition of the fluorides. Each data series had a correlation coefficient between 0.98 and 0.99 . The data followed the predicted trend, i.e., the powder blends containing smaller fluorides had higher flow times than those with larger fluorides due to the higher surface area to volume ratio of the smaller particles. Furthermore, the flow times of the wider 45 to $106 \mu \mathrm{m}$ and 63 to $106 \mu \mathrm{m} \mathrm{BaF}_{2}-\mathrm{CaF}_{2}$ particle size distributions were generally higher than the flow times of the narrower size distributions of fluorides. The flow of the powder blend with 38 to $45 \mu \mathrm{m}$ $\mathrm{BaF}_{2}-\mathrm{CaF}_{2}$ was considerably worse than all other $\mathrm{BaF}_{2}-\mathrm{CaF}_{2}$ sizes considered in this study. In fact, at $4 \mathrm{wt} \% \mathrm{BaF}_{2}-\mathrm{CaF}_{2}$ for this particle size, the powder was no longer free flowing. This confirms previous findings, which showed that the Hall flowmeter provided an effective gauge of powder flowability in the plasma spray system.

The flow time is inversely proportional to the specific volume of the powder, which increases with increasing concentration of the fluorides due to the lower density of the fluorides. The intercepts of the lines representing the flow time versus concentration of fluorides are inversely proportional to the quantity of the size of the fluorides minus the width of the $\mathrm{BaF}_{2}-\mathrm{CaF}_{2}$ particle distribution. There is some overlap in the data between separate $\mathrm{BaF}_{2}-\mathrm{CaF}_{2}$ size ranges, but regression analysis indicates that a single line cannot be used to represent all of the data. The difference between the highest and lowest flow times 
at any given $\mathrm{BaF}_{2}-\mathrm{CaF}_{2}$ concentration was typically less than 6 percent. The variation in individual measurements was approximately 2 percent. Based on the physical characteristics of the powders, the following semi-empirical relationship between flow time, powder density, $\mathrm{BaF}_{2}-\mathrm{CaF}_{2}$ constituent concentration and $\mathrm{BaF}_{2}-\mathrm{CaF}_{2}$ particle size is offered (derived from regression analysis of the measured data):

$$
t=\frac{c_{1}}{\rho} x+\frac{c_{0}}{d_{m}-w}
$$

where $t$ is the flow time in seconds, $\rho$ is the theoretical density of the powder, $x$ is the weight percent $\mathrm{BaF}_{2}-\mathrm{CaF}_{2}$ in the powder blend, $d_{m}$ is the mean diameter of the fluorides, and $w$ is the width of the particle size distribution in microns. For this powder blend, $d_{m}>w$. The theoretical density of the powder is determined by the rule of mixtures. ${ }^{*}$ The constants $c_{1}$ and $c_{0}$ in the equation are governed by physical characteristics such as particle shape and shape distribution, surface chemistry, and density of the surrounding environment. The parameters from the equation, as determined from the regression analysis, are listed in table 1.

The theoretical density of the $\mathrm{BaF}_{2}-\mathrm{CaF}_{2}$ is approximately $4.01 \mathrm{~g} / \mathrm{cm}^{3}$. The theoretical densities of nichrome, chromia and silver are $8.57,5.22$, and $10.49 \mathrm{~g} / \mathrm{cm}^{3}$, respectively. Therefore, increasing the concentration of fluorides decreases the bulk density of the powder blend. This causes the volume of the $50 \mathrm{~g}$ flowmeter charge to increase. The increase in the flow time of the powder blend due to increased volume can be predicted in part by the rule of mixtures. Using this method, the volume of the PS304 feedstock powder is expected to increase linearly with increasing fluorides content. Therefore, the flow time of a $50 \mathrm{~g}$ sample with $10 \mathrm{wt} \%$ fluorides would be expected to take about 9 percent longer to flow through the Hall flowmeter than a $50 \mathrm{~g}$ sample with no fluorides due to the increase in volume alone. The measured flow time at $10 \mathrm{wt} \% \mathrm{BaF}_{2}-\mathrm{CaF}_{2}$ was an average of 17 percent higher than the flow time with no fluorides. This indicates that, while the flow behavior of this powder may be influenced by the density of the powder blend, there are other factors that must be accounted for in order to accurately describe the flow behavior. The positive deviation in flow time from the rule of mixtures calculation is thought to be due to the interparticle friction and its resulting increase on the flow time of the powder blend. The derived equation is an attempt to characterize the flow behavior in terms of density, size and size distribution, and the constants mentioned previously.

Table 2 lists the tapped density, apparent density and Hausner Ratio for each feedstock powder. The Hausner Ratio was less than 1.5 in each case, including the non-free flowing powder containing $4 w t \%$ 38 to $45 \mu \mathrm{m}$ fluorides. Also, Hausner Ratio measurements varied by less than 2 percent for free flowing powders and by a maximum of 4 percent between the powder with the highest flow rate (containing 90 to $106 \mu \mathrm{m}$ fluorides) to the non-free flowing powder (containing 38 to $45 \mu \mathrm{m}$ fluorides). Low sensitivity of Hausner Ratio measurements was reported previously [30]. For comparison, the Hausner Ratio for coarse $(>150 \mu \mathrm{m})$ free flowing emery powder was 1.20 (15 percent lower than the non free-flowing PS304 feedstock).

\footnotetext{
B By the rule of mixtures, density is given by $\rho=\sum_{i} v_{i} \cdot \rho_{i}(i=1$ to 4$)$, where the volume fraction $v_{i}$ is a function of the weight fraction of constituent $i$. This calculation assumes no interaction between particles.
} 


\section{Conclusions}

The objective of this study was to investigate the effects of $\mathrm{BaF}_{2}-\mathrm{CaF}_{2}$ particle size and size distribution on the flow properties of PS304 feedstock. Based on the results, the following conclusions were drawn.

1. Flow was degraded with smaller $\mathrm{BaF}_{2}-\mathrm{CaF}_{2}$ particle size, wider particle size distributions and increasing concentration of fluorides.

2. Interparticle friction increases linearly with increasing concentration of fluorides.

3. A semi-empirical relationship was found between powder flow rate, density, concentration of fluorides and particle size, which is based on flow measurement and change in theoretical density.

4. The Hausner Ratio was insensitive to differences in $\mathrm{BaF}_{2}-\mathrm{CaF}_{2}$ particle size in PS304 feedstock. However, the Hall flow time was able to distinguish different $\mathrm{BaF}_{2}-\mathrm{CaF}_{2}$ particle sizes.

\section{References}

1. C. DellaCorte, V. Lukaszewicz, M.J. Valco, K.C. Radil and H. Heshmat. 2000. Performance and Durability of High Temperature Foil Air Bearings for Oil-Free Turbomachinery. Tribology Transactions 43, no. 4: 744-80.

2. C. DellaCorte, and J.C. Wood. 1994. High Temperature Solid Lubricant Materials for Heavy Duty and Advanced Heat Engines. NASA TM-106570.

3. J.A. Laskowski, and C. DellaCorte. 1996. Friction and Wear Characteristics of Candidate Foil Bearing Materials from $25^{\circ} \mathrm{C}$ to $800^{\circ} \mathrm{C}$. Lubrication Engineering 52: 605-12.

4. C. DellaCorte, and B.J. Edmonds. 1996. Preliminary Evaluation of PS300: A New Self-Lubricating High Temperature Composite Coating for Use to $800^{\circ} \mathrm{C}$. NASA TM-107056.

5. C. DellaCorte, 1998. The Evaluation of a Modified Chrome Oxide Based High Temperature Solid Lubricant Coating for Foil Gas Bearings. NASA/TM-1998-208660.

6. C. DellaCorte, 1998. Evaluation of Advanced Solid Lubricant Coatings for Foil Air Bearings Operating at 25 and $500{ }^{\circ} \mathrm{C}$. NASA/TM-1998-206619.

7. Freeman, Reg. 2001. An Insight Into the Flowability and Characterization of Powders. American Laboratory 33, no. 16: 13-16.

8. B.J. Ennis, 1997. Unto dust shalt thou return. In Powders \& Grains 97: Proceedings of the Third International Conference on Powders and Grains held in Durham, NC, 18-23 May 1997, edited by Robert P. Behringer and James T. Jenkins, 13-23. Rotterdam, Netherlans: A.A. Balkema.

9. E. Teunou, J.J. Fitzpatrick and E.C. Synnott. 1999. Characterization of Food Powder Flowability. Journal of Food Engineering 39: 31-7.

10. B.K. Kim, D.W. Lee, and G.H. Ha. 2001. Plasma Spray Coating of Spray-Dried $\mathrm{Cr}_{2} \mathrm{O}_{3} / 3 \mathrm{wt} \% \mathrm{TiO}_{2}$ Powder. Journal of Thermal Spray Technology 10, no. 1: 133-37.

11. C. DellaCorte, and B.J. Edmonds. 1999. U.S. Patent 5,866,518.

12. H.S. Ingham, and A.P. Shepard. 1965. Flame Spray Handbook. New York: Metco.

13. C. DellaCorte, and B.J. Edmonds. 1999. Unpublished report.

14. J.S. Reed, 1988. Introduction to the Principles of Ceramic Processing. New York: John Wiley \& Sons.

15. T. Tanaka, and Y. Kanda. 1997. Crushing and Grinding. In Powder Technology Handbook, 2 d ed., rev. and exp. New York: Marcel Dekker, Inc.

16. C. Orr, 1966. Particulate Technology. New York: The Macmillan Company.

17. G.C. Lowrison, 1974. Crushing and Grinding: The Size Reduction of Solid Materials. Cleveland: CRC Press, Inc.

18. S.G. Malghan, 1991. Comminution. In Engineered Materials Handbook. Vol. 4, Ceramics and Glasses. Materials Park, OH: ASM International. 
19. A.D. Zimon, 1982. Adhesion of Dust and Powder. 2 d ed., rev. and enl. Translated by Robert K. Johnston. New York: Consultants Bureau.

20. B. Frisch, 1988. Characterization of Powder and Pressings Based on Geometric Fundamentals. In Ceramic Powder Processing Science: Proceedings of the Second International Conference held in Berchtesgaden (Bavaria) FRG 12-14 October 1988, edited by H. Hausner, G.L. Messing and S. Hirano, 385-414. Cologne: Deutsche Karamische Gesellschaft.

21. R.M. German, 1989. Particle Packing Characteristics. New Jersey: Metal Powder Industries Federation.

22. R.L. Carr, 1965. Evaluating Flow Properties of Solids. Chemical Engineering 72, no. 2: 163-68.

23. R.M. German, 1984. Powder Metallurgy Science. Princeton: Metal Powder Industries Federation.

24. M.K. Stanford, C. DellaCorte, and D. Eylon. 2001. Particle Morphology Effects on Flow Characteristics of PS304 Plasma Spray Coating Feedstock Powder Blend (to be published).

25. M.K. Stanford, and C. DellaCorte. 2001. Effects of Humidity on Flow Characteristics of PS304 Plasma Spray Coating Feedstock Powder Blend (to be published).

26. ASTM B 213 - 97. 1998. Standard Test Method for Flow Rate of Metal Powders. Annual Book of ASTM Standards, Vol. 02.05. West Conshohocken, PA: American Society for the Testing of Materials.

27. H.H. Hausner, 1967. Friction Conditions in a Mass of Metal Powder. International Journal of Powder Metallurgy 3, no. 4: 7-13.

28. R.O. Grey, and J.K. Beddow. 1969. On the Hausner Ratio and Its Relationship to Some Properties of Metal Powders. Powder Technology 2: 323-26.

29. L.G. Austin, 1997. Size Reduction of Solids: Crushing and Grinding Equipment. In Handbook of Powder Science and Technology. 2d ed. Edited by M.E. Fayed and L. Otten, 584-634. New York: Van Nostrand Reinhold Company.

30. S.M. Tasirin, 2000. The Effect of Fines on Flow Properties of Binary Mixtures. Chemical Engineering Communications 179: 101-15.

Table 1.-Parameters from Eq. (1)

\begin{tabular}{|l|c|c|c|c|}
\hline \multicolumn{1}{|c|}{$\mathrm{BaF}_{2}-\mathrm{CaF}_{2}$ particle size } & Screen size & $(d-w)^{-1}$ & $c_{0}$ & $c_{1}$ \\
\hline 38 to $45 \mu \mathrm{m}$ & $-325+400$ & 0.0290 & 845.25 & 14.236 \\
\hline 45 to $106 \mu \mathrm{m}$ & $-270+325$ & 0.0690 & 1.8140 & 3.6932 \\
\hline 63 to $106 \mu \mathrm{m}$ & $-230+325$ & 0.0282 & 0.7277 & 3.9766 \\
\hline 45 to $53 \mu \mathrm{m}$ & $-270+325$ & 0.0243 & 0.6365 & 2.6013 \\
\hline 63 to $75 \mu \mathrm{m}$ & $-200+230$ & 0.0175 & 0.4409 & 3.9085 \\
\hline 90 to $106 \mu \mathrm{m}$ & $-140+170$ & 0.0122 & 0.3055 & 3.2118 \\
\hline
\end{tabular}


Table 2.-Tapped density, apparent density and Hausner Ratio measurements for the powder blends containing $10 \mathrm{wt} \% \mathrm{BaF}_{2}-\mathrm{CaF}_{2}$ except as noted

\begin{tabular}{|l|c|c|c|}
\hline $\mathrm{BaF}_{2}-\mathrm{CaF}_{2}$ Particle Size & Tapped Density & Apparent Density & Hausner Ratio \\
\hline 38 to $45 \mu \mathrm{m}^{\mathrm{a}}$ & 4.292 & 3.024 & 1.42 \\
\hline 45 to $106 \mu \mathrm{m}$ & 4.00 & 2.87 & 1.39 \\
\hline 63 to $106 \mu \mathrm{m}$ & 4.00 & 2.92 & 1.37 \\
\hline 45 to $53 \mu \mathrm{m}$ & 3.92 & 2.85 & 1.38 \\
\hline 63 to $75 \mu \mathrm{m}$ & 4.00 & 2.89 & 1.38 \\
\hline 90 to $106 \mu \mathrm{m}$ & 4.00 & 2.95 & 1.36 \\
\hline
\end{tabular}

${ }^{\mathrm{a}}$ This powder blend contained $4 \mathrm{wt} \% \mathrm{BaF}_{2}-\mathrm{CaF}_{2}$. The apparent density was measured using the Carney flowmeter funnel as described in ASTM B 417-00.

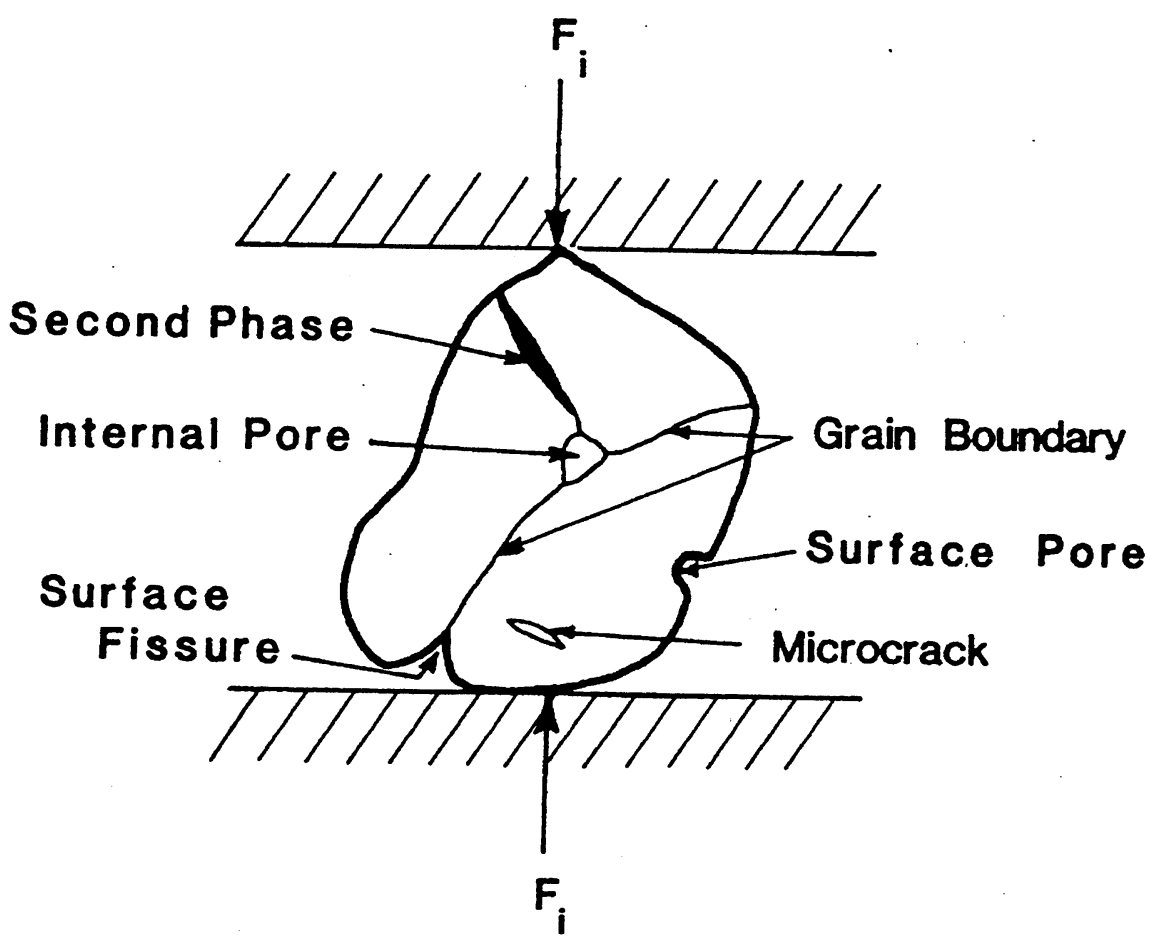

Figure 1.-Defects in ceramic materials that aid comminution processes [14]. 


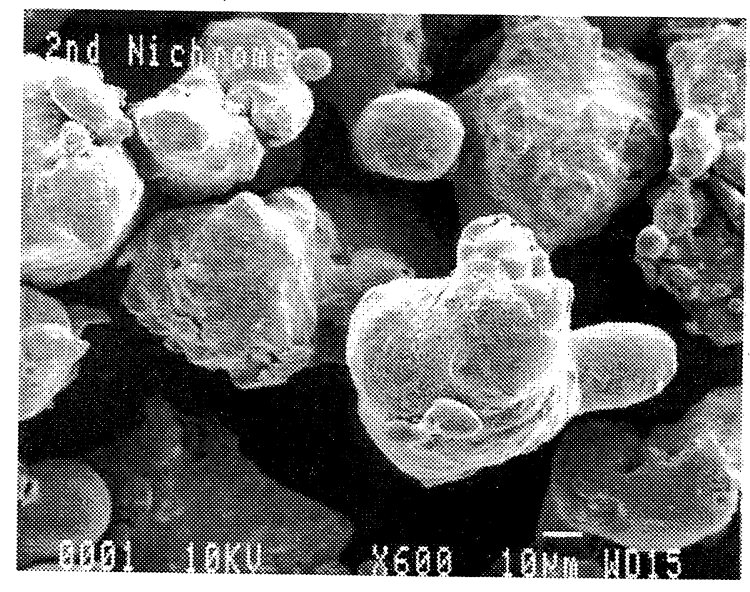

(a) Nichrome

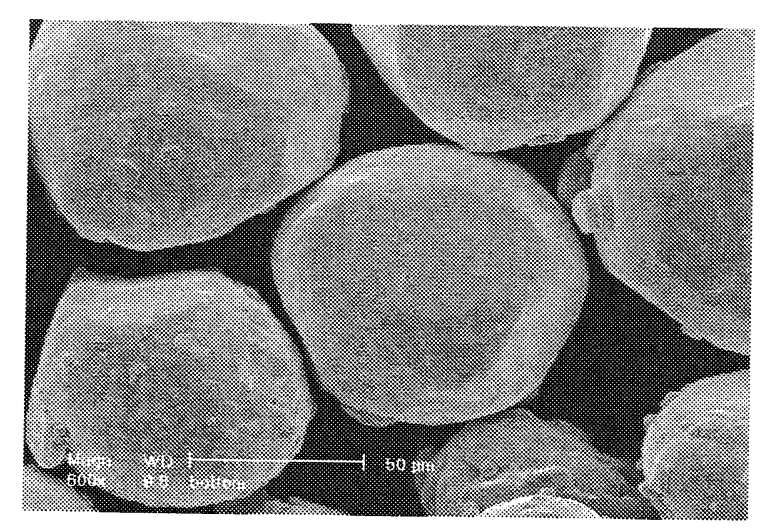

(c) Silver

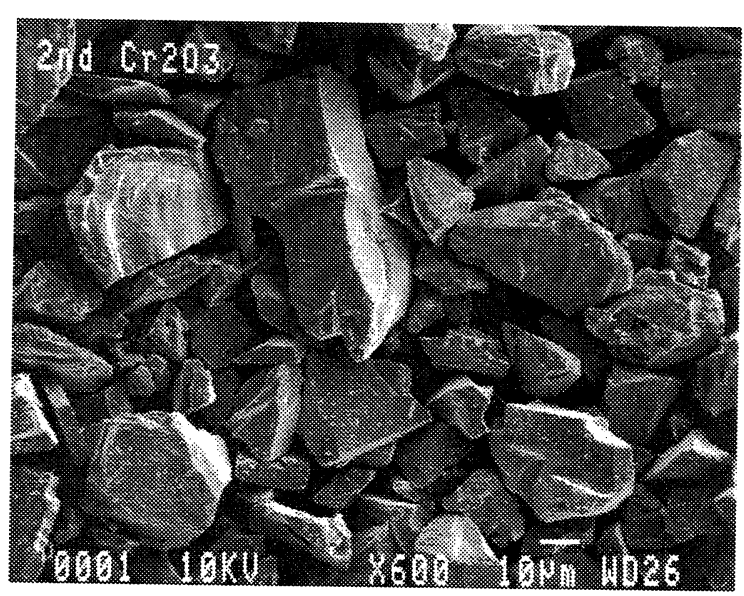

(b) Chromia

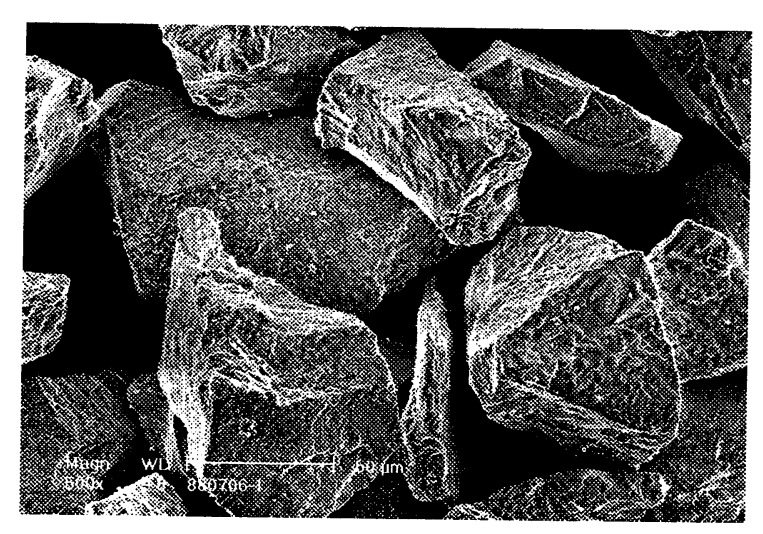

(d) Fluorides

Figure 2.-Powder constituents of PS304 (original magnification 600X). 

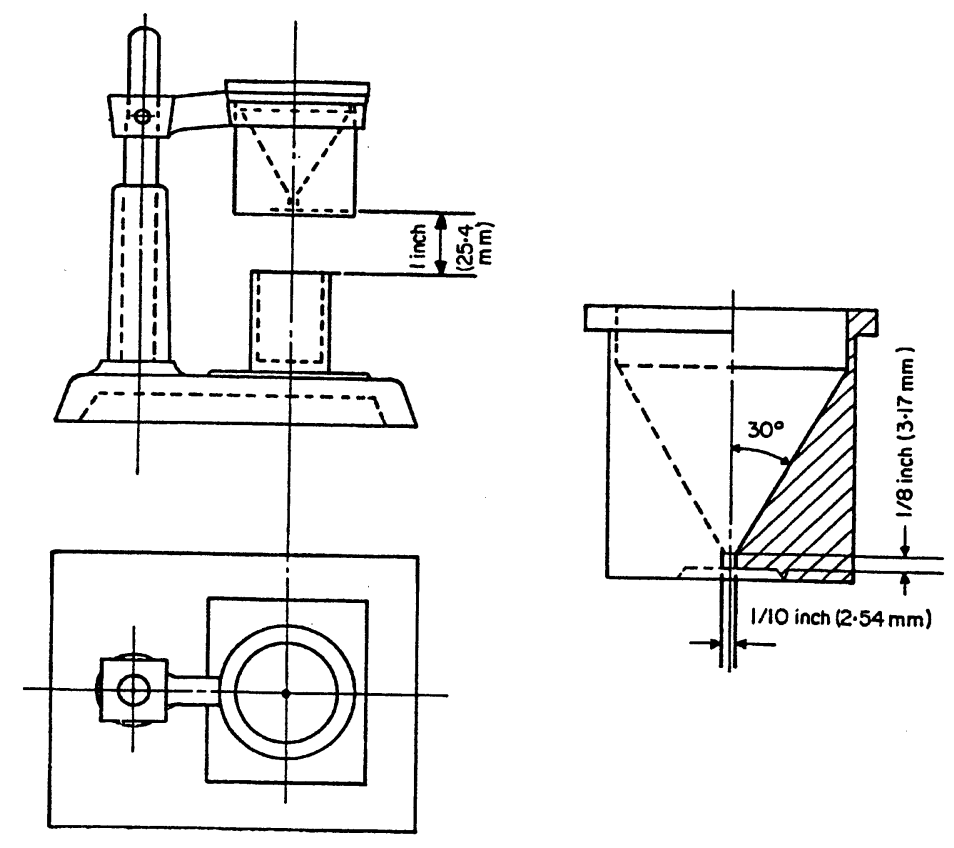

Figure 3.-Hall flowmeter [26].

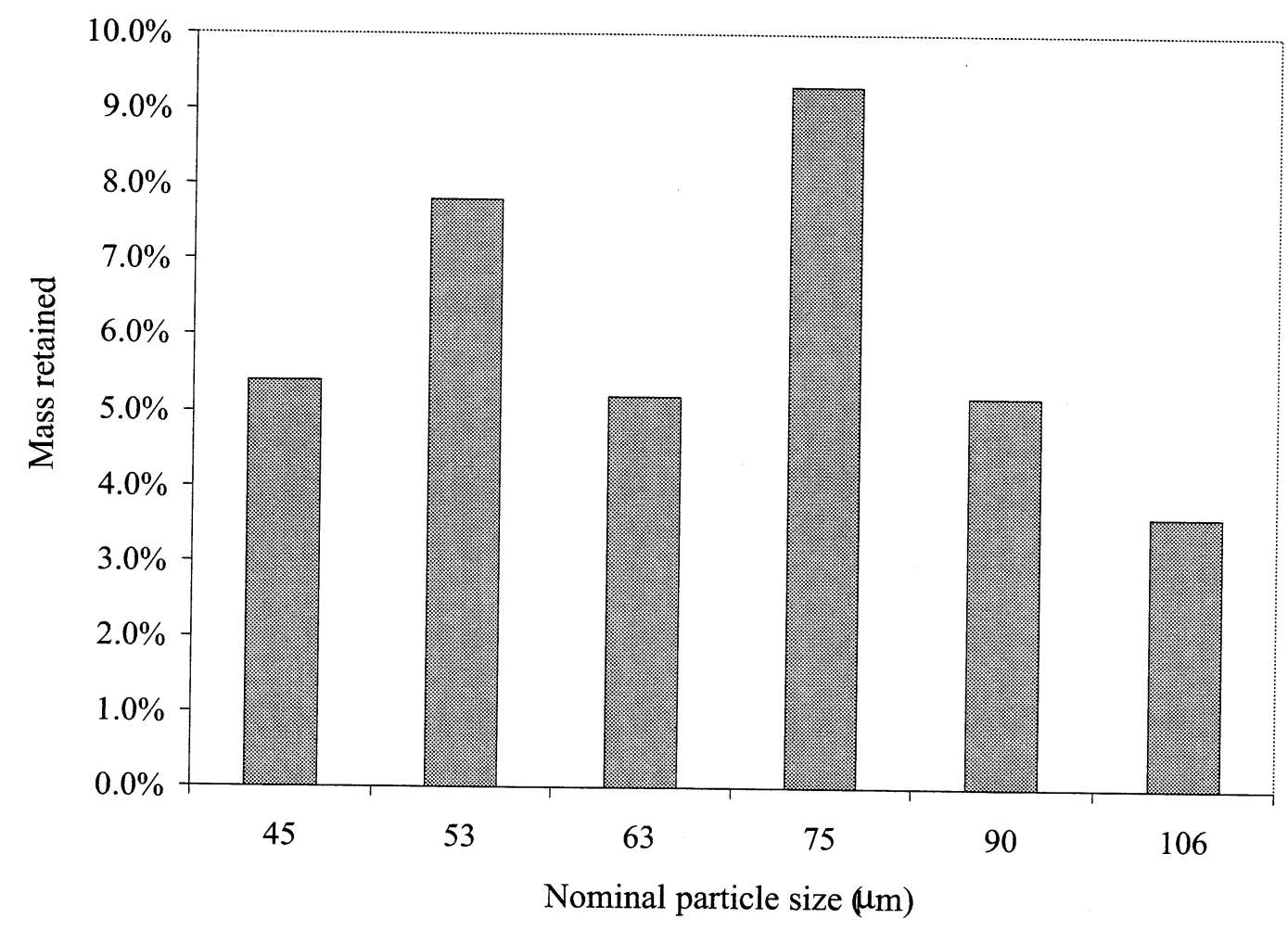

Figure 4.- Percentage of $\mathrm{BaF}_{2}-\mathrm{CaF}_{2}$ powder retained per screening run. 


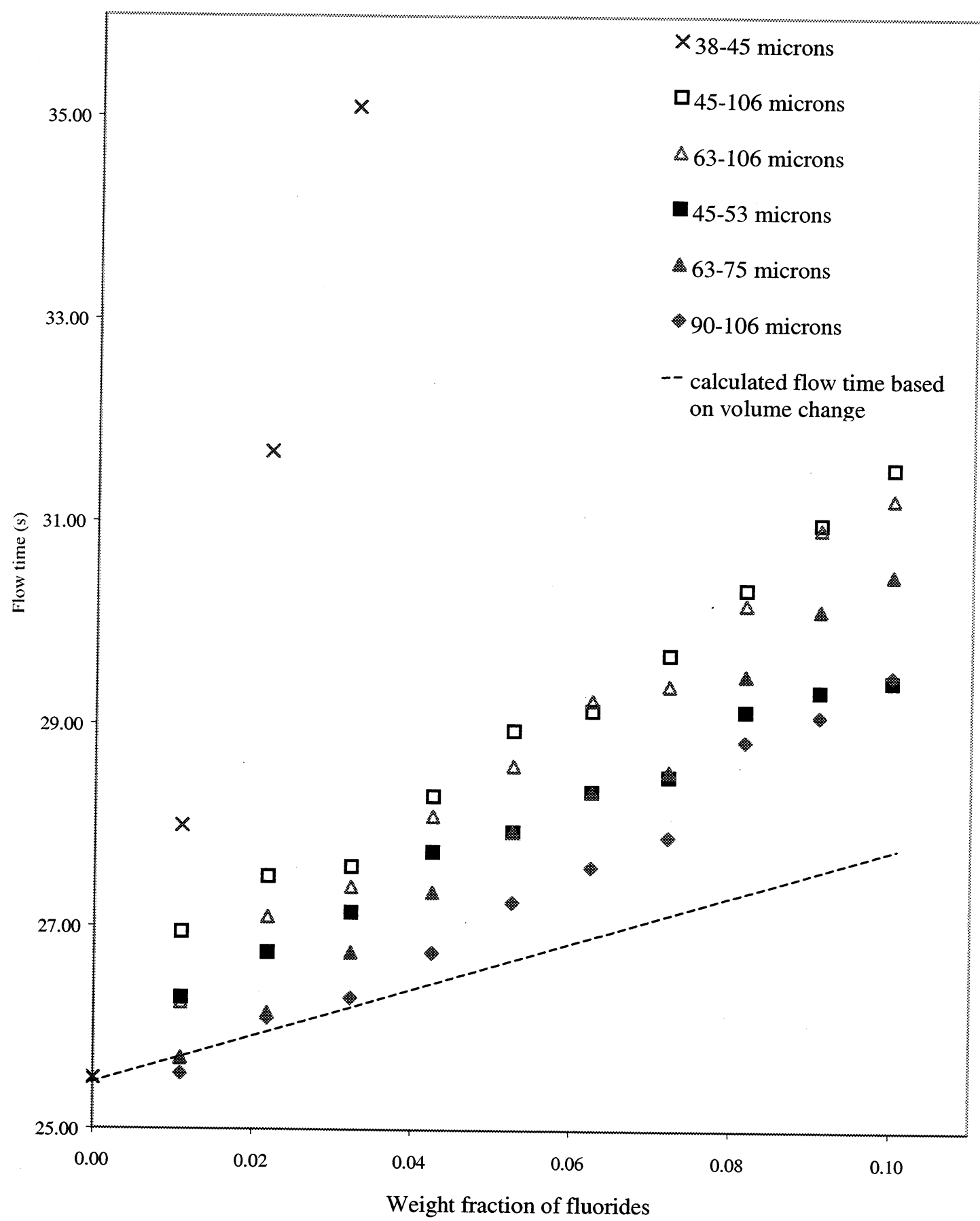

Figure 5.- $\mathrm{PS} 304$ feedstock flow time versus $\mathrm{BaF}_{2}-\mathrm{CaF}_{2}$ concentration for various $\mathrm{BaF}_{2}-\mathrm{CaF}_{2}$ particle sizes. 


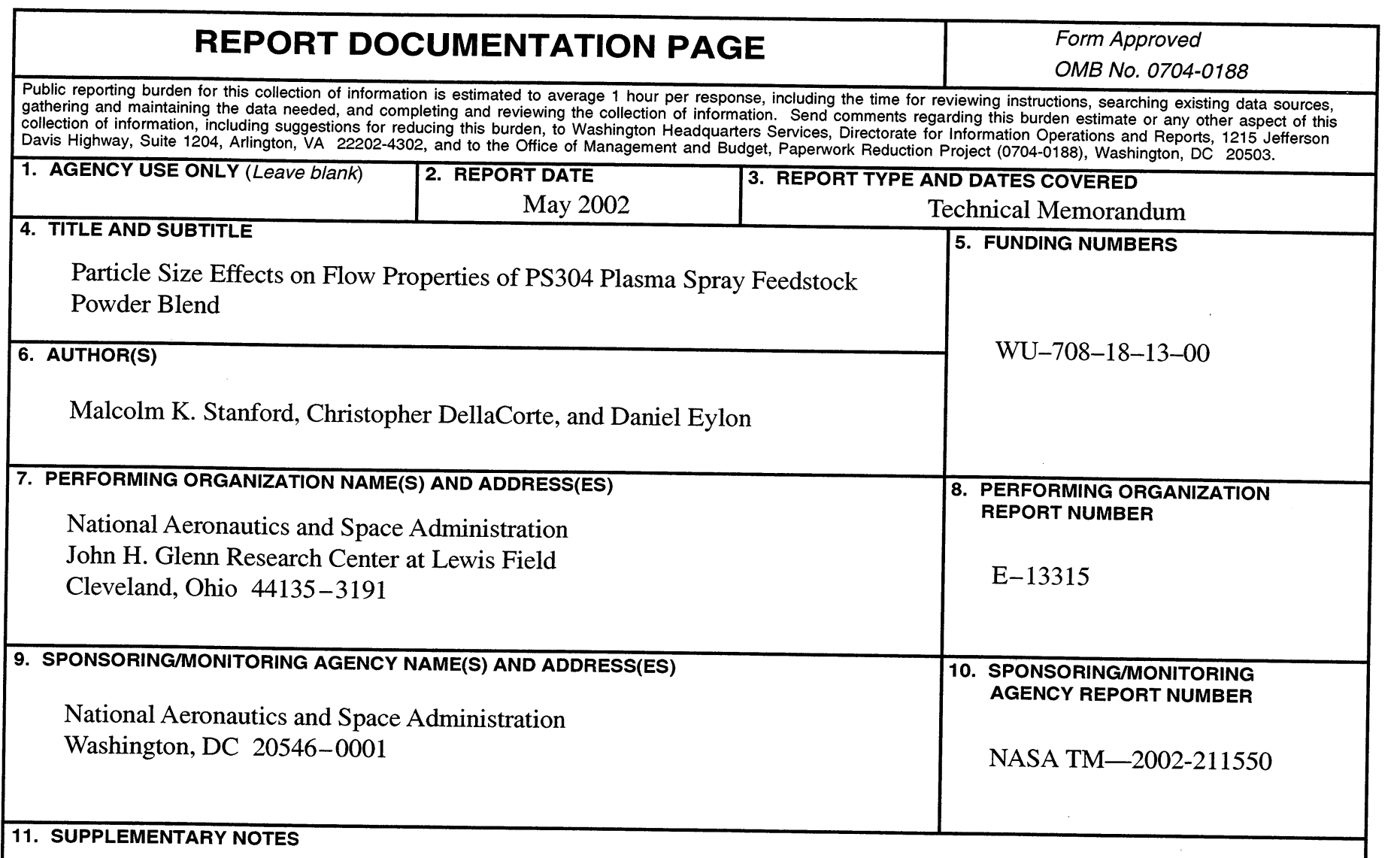

Malcolm K. Stanford and Daniel Eylon, University of Dayton, Materials Engineering, 300 College Park, Dayton, Ohio 45469-0121, and Christopher DellaCorte, NASA Glenn Research Center. Responsible person, Christopher DellaCorte, organization code 5960, 216-433-6056.

12a. DISTRIBUTION/AVAILABILITY STATEMENT

12b. DISTRIBUTION CODE

Unclassified - Unlimited

Subject Category: 23

Distribution: Nonstandard

Available electronically at http://gltrs.gxc.nasa.gov/GLTRS

This publication is available from the NASA Center for AeroSpace Information, 301-621-0390.

13. ABSTRACT (Maximum 200 words)

The effects of $\mathrm{BaF}_{2}-\mathrm{CaF}_{2}$ particle size and size distribution on PS304 feedstock powder flowability have been investigated. Angular $\mathrm{BaF}_{2}-\mathrm{CaF}_{2}$ eutectic powders were produced by comminution and classified by screening to obtain 38 to $45 \mu \mathrm{m}$, 45 to $106 \mu \mathrm{m}, 63$ to $106 \mu \mathrm{m}, 45$ to $53 \mu \mathrm{m}, 63$ to $75 \mu \mathrm{m}$, and 90 to $106 \mu \mathrm{m}$ particle size distributions. The fluorides were added incrementally from 0 to $10 \mathrm{wt} \%$ to the other powder constituents of the PS304 feedstock: nichrome, chromia, and silver powders. The flow rate of the powder blends decreased linearly with increasing concentration of the fluorides. Flow was degraded with decreasing $\mathrm{BaF}_{2}-\mathrm{CaF}_{2}$ particle size and with increasing $\mathrm{BaF}_{2}-\mathrm{CaF}_{2}$ particle size distribution. A semiempirical relationship is offered to describe the PS304 powder blend flow behavior. The Hausner Ratio confirmed the funnel flow test results, but was slightly less sensitive to differences in $\mathrm{BaF}_{2}-\mathrm{CaF}_{2}$ particle size and size distribution. These findings may have applicability to other powders that do not flow easily, such as ceramic powders.

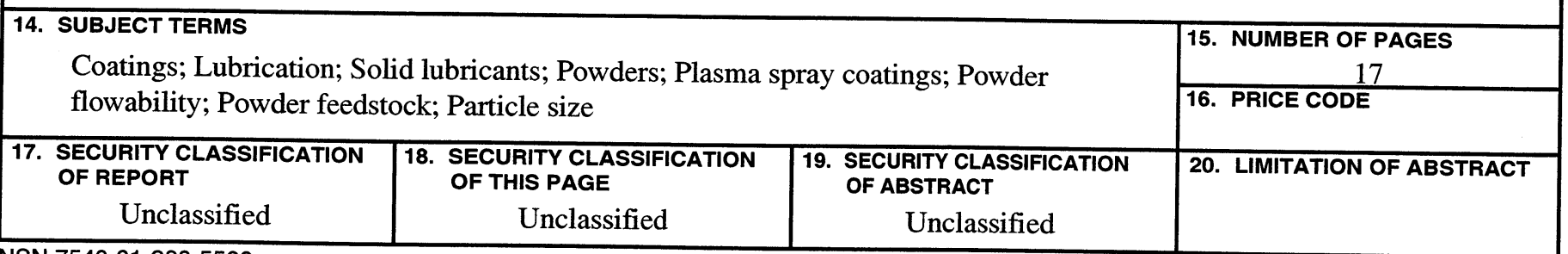

